\title{
Growth Response of Melati Plant Plant (Jasminum Sambac L.) Against Types of Media Plants and Types of Growing Agents
}

\author{
Yuliatul Muslimah', Sumeinika Fitria Lizmah' ${ }^{\mathbf{1},}$ Nur Fayanti $^{\mathbf{2}}$ \\ ${ }^{1}$ Lecturer in Agrotechnology Study Program, Faculty of Agriculture, Teuku Umar University \\ ${ }^{2}$ Alumni Agrotechnology Study Program, Faculty of Agriculture, Teuku Umar University \\ sumeinikafitrializmah@utu.ac.id
}

\begin{abstract}
Propagation of jasmine plants by cuttings often experience obstacles, especially to grow roots. Proper planting media and application of growth regulators (PGR) have an important role in the growth and development of plant cuttings roots. The purpose of this study was to determine the effect of planting media types and PGR on the growth of jasmine cuttings. This research was conducted in the experimental garden of the Faculty of Agriculture, Teuku Umar University, in March - May 2019. This study used a completely randomized design (CRD) with a factorial pattern of $3 \times 3$ with three replications. The treatment factors studied were (1) the type of planting media consisted of 3 levels namely alluvial soil, sand and husk charcoal, and (2) the type of growth regulator (ZPT) consisted of 3 levels namely control (without zpt), chemical (growtone) and organic (shallot extract). $F$ test results on the analysis of variance showed that the planting medium had a very significant effect on the number of shoots 35 and 45 HST, number of leaves 15, 35 and 45 HST number of roots, root length, percentage of live cuttings. But the planting media had no significant effect on the number of shoots of 15 DAP. Growth regulator substances have a very significant effect on the number of shoots 35 HST, number of leaves 15, 35 and 45 HST, number of roots and root length. Significantly affect the number of shoots 45 HST and percentage of live cuttings, but no significant effect on the number of shoots 15 HST. This shows that the difference in growth of jasmine plant cuttings due to different planting media does not depend on growth regulators, and vice versa.
\end{abstract}

Keywords: Jasmine; Alluvial; Sand; Husk Charcoal; Growtone and Shallot Extract

\section{Introduction}

Agricultural land is increasingly narrow due to the shifting of the function of agricultural land into industrial areas, so that hydroponic cultivation is considered appropriate to utilize available land because this cultivation system does not require soil media. (Zailani, 2019)

Jasmine plant (Jasminum sambac) is an ornamental flower plant in the form of upright trunked shrubs that live yearly. In 1665 in England cultivated white jasmine (J. Sambac) which was introduced by Duke Casino de 'Meici. Jasmine plants included in the Oleaceae tribe are essential oil-producing plants known as jasmine oil, originating from India and then spread to Malaysia, the Philippines, China, and Indonesia. In Indonesia, the most common type of jasmine is white jasmine (Jasminum sambac) which is used for sowing flowers and flower arrangements (Maulana, 2007).

Jasmine plants better known as medicinal plants, among others, can stop excessive milk coming out, cure eye pain, swelling due to bee attacks, fever and headaches, and shortness of breath (Maulana, 2007). The need for jasmine plants is increasing, jasmine plants also have 
bright prospects in the future as an export commodity.

Propagation of traditional jasmine by stem cuttings encountered many obstacles, including the quality of the resulting seed is not good. Rooted cuttings and sprouts are not too high, low flower development. The root constraints can be reduced by giving growth substances (Wuryaningsih, 2008).

Planting media have an important role as a medium for root growth and development, especially in cuttings. The use of appropriate plant media will provide optimum environmental conditions. According to Winarso (2003), good media can absorb water and other substances needed by plants. The results of research on some parts of jasmine cuttings planting were reported that the media of husk charcoal, zeolite (the size of grains of sand) and sand were good alternative media (Wuryaningsih, 2008), in the study used mixed media of soil, sand and husk charcoal (Wuryaningsih, 2008). A good growing media has good porosity, aeration, drainage and high water binding capacity and is pathogen free.

Provision of growth regulators aims to accelerate root growth. Plant growth regulators or plant hormones are a group of organic compounds that are formed naturally or artificially in very low concentrations able to influence plant physiology processes such as pushing, inhibiting, or changing the growth, development, and movement (taxis) of plants (Davis, 2010). Giving exogenous growth regulators (ZPT) can accelerate root growth in stem cuttings. Shallots, coconut water and bean sprouts can be used as growth regulators which can stimulate the growth of cuttings (Alam et al., 2004).

Research Nature et al. (2004), showed that shallots contain auxin hormones (IAA, NAA, 2,4 D) and cytokines (BAP). The results of the study of Setyowati (2004), the use of onion extract concentration of $20 \%$ gave better results when the shoots and number of leaves appeared compared to other treatments. Shallot extract contains auxin and rhizokalin which can stimulate root growth. According to Artati (2007), growth regulators (ZPT) have been used in various types of plant cuttings such as jasmine cuttings (Marfirani et al., 2014), Tin seed cuttings (Marpaung and Hutabarat, 2015) and guava cuttings (Mayasari et al. , 2012).

\section{Research Methods}

\subsection{Place and time of research}

This research was conducted in the experimental garden of the Faculty of Agriculture, Teuku Umar Meulaboh University, West Aceh, from March to May 2019.

\subsection{Experimental design}

This study uses a completely randomized design (CRD) factorial pattern of $3 \times 3$ each consisting of 3 replications. The treatment factors studied were the type of planting media and the type of natural PGR, namely onion extract and growtone. The type of planting media consists of 3 levels, namely: $\mathbf{M}_{1}$ (alluvial soil), $\mathbf{M}_{2}$ (sand), $\mathbf{M}_{3}$ (husk charcoal). Types of natural growth regulator substances (ZPT) consist of 3 levels, namely $\mathrm{Z}_{0}$ (control: without $\mathrm{zpt}$ ), $\mathrm{Z}_{1}$ (chemical (Growtone), $\mathrm{Z}_{2}$ (organic: shallot extract).

\subsection{Preparation of planting media}

The soil used in this research is alluvial, sand media and husk charcoal. Each planting media is cleaned from the dirt inside, then put in a polybag in accordance with the treatment media, namely soil, sand and charcoal husk. The number of polybags used was 135 polybags measuring

$15 \times 15$. 


\subsection{Preparation of cutting material}

Material used in cuttings is healthy, not too old or too young, usually comes from the tip of the stem and can come from the middle or base of the stem (taken from the stem of the base of the jasmine plant). Checking according to the needs of the number of treatments, a clean and sterile place to support the growth of the results of cuttings

The planting material is cut with a knife cuttings, cuttings are cut at $45 \%$. This was done to expand the field of cuttings. Each cuttings consists of two books and one leaf. Cuttings are taken from the center of the stem. Before being cuttings, cuttings are immersed in a bucket of water to avoid excessive transpiration (Tustiyani, 2017).

\subsection{Making shallot ZPT}

Onion is provided as much as $1 \mathrm{~kg}$, cleaned by peeling the outer skin, washed clean so as not to mix with other substances. Furthermore, shallots are ground first and then mashed using a blender, $50 \mathrm{ml}$ of water is added, then filtered and the onion extract is ready to be applied (Aulia et al., 2014).

\subsection{Application of zpt}

Zpt was applied according to the treatment, with the amount of Growtone concentration of $20 \%$ and onion extract $75 \%$. Each zpt was applied to the cuttings by soaking for 30 minutes. Furthermore, cuttings are planted in the planting medium according to treatment

\subsection{Planting}

Cuttings that are ready to be planted are plugged into the planting media by inserting cuttings that have been soaked into the planting media (polybags), by making a hole in the middle of the media and cuttings planted with a depth of $\pm 2 \mathrm{~cm}$.

\subsection{Enclosure}

Enclosure is done using clear white plastic, making hoods by covering the entire plant, before planting the cuttings are complete. This containment serves so that the plant is always in a humid state, in order to accelerate the growth process and avoid direct sunlight, given a lid and a black paranet.

\subsection{Maintenance}

Maintenance includes (1) Watering is done 2 times a day, done in the afternoon, unless the rain watering is eliminated. (2) Stitching if a plant dies, or growth is inhibited. Replacing is replaced with a reserve plant. (3) Weeding is carried out on weeds that grow around the plant in polybags and outside polybags. Weeding is done by pulling weeds by hand.

\subsection{Observation}

1. Percentage of live cuttings (\%) observed at 45 days after planting (HST)

Observations were made at the age of $45 \mathrm{HST}$, with the formula:

Life cuttings $=$ Total life cutting $\times 100 \%$

Total plant cutting

1. The number of roots observed at 45 days after planting (HST), namely by counting all the number of roots that grow on J. sambac cuttings.

2. Root length $(\mathrm{cm})$ is measured at 45 days after the plant (HST), measured from the root base to the tip of the root by straightening the rolled roots.

3. The number of shoots is observed at the age of 15, 35 and 45 days after planting (HST), ie by counting the shoots that appear. 
4. The number of leaves (strands) calculated 15, 35 and 45 days after planting (HST), is done by counting the number of leaves that come out of cuttings in pieces.

\section{Discussion}

\subsection{Influence of Growing Media}

\section{a. Number of Buds}

The results showed that the highest number of buds of jasmine cuttings 35 and 45 HST were found in the treatment of rice husk $\left(\mathrm{M}_{3}\right)$ media which was significantly different from the treatment of sand planting media $\left(\mathrm{M}_{2}\right)$, but not significantly different from the treatment of alluvial soil planting media $\left(M_{1}\right)$. Whereas the number of 15 HST jasmine cuttings buds did not show significant differences in the various planting media used (Table 1).

The number of jasmine cuttings of 15 HST cuttings did not show any significant difference in the various planting media used. This is because at the beginning of the growth of cuttings have not been able to absorb nutrients found in each planting media. In this condition cuttings only utilize food reserves contained in cuttings material in limited quantities. Sitompul and Guritno (1995) in Santoso (2011) also stated that the use of food reserves by cuttings will produce energy that can encourage bud bursts and meristem tissue at the point where shoots grow more actively.

Table 1. The average number of jasmine cuttings buds 15, 35 and HST on Various planting media

\begin{tabular}{lccc}
\hline \multirow{4}{*}{ Handling } & \multicolumn{4}{c}{ 15 HST } & 35 HST & 45 HST \\
\cline { 2 - 4 } & 1,22 & $2,30 \mathrm{~b}$ & $3,41 \mathrm{~b}$ \\
Alluvial soils $\left(\mathrm{M}_{1}\right)$ & 1,00 & $1,70 \mathrm{a}$ & $2,78 \mathrm{a}$ \\
Sand $\left(\mathrm{M}_{2}\right)$ & 1,30 & $2,74 \mathrm{~b}$ & $3,96 \mathrm{~b}$ \\
Chaff Charcoal $\left(\mathrm{M}_{3}\right)$ & - & 0,45 & 0,61 \\
\hline \multicolumn{1}{c}{$\mathrm{BNT}_{0,05}$} & - & & \\
\hline
\end{tabular}

Note: Numbers followed by the same letters in the same column that are not significantly different in the $\mathrm{BNT}_{0.05}$ test

At the age of 35 and 45 HST showed the highest number of jasmine cuttings buds in the treatment of husk charcoal planting media $\left(\mathrm{M}_{3}\right)$. This is because the roots have developed well so that the absorption of nutrients available to the media occurs properly. The husk charcoal media has a pivot texture and the availability of $\mathrm{N}$ elements thus increasing bud growth. According to Wulandari et al. (2017), husk charcoal can increase fertility because it contains $\mathrm{N}$ which is $0.18 \%$. Prameswari et al. (2014) states that nitrogen nutrients function to increase vegetative growth, Hayati et al. (2012) added that nitrogen influences the formation of stems and plays a role in the vegetative phase of the plant which plays a role in the formation of shoots and stem development.

In addition, the use of alluvial soil also showed results that were not significantly different from the treatment of rice husk planting media $\left(\mathrm{M}_{3}\right)$ at ages 35 and 45 HST. 
The growth of shoots in alluvial media is suspected because alluvial soil availability of nutrients in the alluvial land is sufficient for cuttings to grow new shoots. According to Geologinesia (2018), alluvial soils are derived from sediment material and are closely related to the accumulation of erosion materials, so that alluvial soils are rich in nutrient sources. Weathering of minerals in alluvial soils produces macro nutrients $\mathrm{N}$, $\mathrm{P}$ and $\mathrm{K}$ which are needed for plant growth

\section{b. Number of Leaves (Strands)}

Table 2 shows that the highest number of leaf 15, 35 and 45 HST of jasmine cuttings was found in the treatment of rice husk $\left(\mathrm{M}_{3}\right)$ media which was significantly different from the treatment of sand planting media $\left(\mathrm{M}_{2}\right)$, but not significantly different from the treatment of alluvial soil planting media $\left(\mathrm{M}_{1}\right)$.

This is because the husk charcoal has mild properties and the capacity to hold water is high so it supports the growth of cuttings. According to Wuryaningsih (1998), other characteristics of husk charcoal are light weight, high air circulation, high water holding capacity, blackish color, so it can absorb sunlight effectively.

Table 2. The average number of jasmine cuttings leaves 15, 35 and HST on Various planting media

\begin{tabular}{lccc}
\hline \multirow{4}{*}{ Handling } & 15 HST & 35 HST & 45 HST \\
\cline { 2 - 4 } & $4,19 \mathrm{~b}$ & $15,89 \mathrm{~b}$ & $24,59 \mathrm{~b}$ \\
Alluvial soils $\left(\mathrm{M}_{1}\right)$ & $3,41 \mathrm{a}$ & $12,56 \mathrm{a}$ & $20,70 \mathrm{a}$ \\
Sand $\left(\mathrm{M}_{2}\right)$ & $4,81 \mathrm{~b}$ & $17,11 \mathrm{~b}$ & $27,81 \mathrm{~b}$ \\
Chaff Charcoal $\left(\mathrm{M}_{3}\right)$ & & & \\
\hline \multicolumn{1}{c}{$\mathrm{BNT}_{0,05}$} & 0,71 & 1,58 & 3,53 \\
\hline
\end{tabular}

Note: Numbers followed by the same letters in the same column that are not significantly different in the $\mathrm{BNT}_{0.05}$ test

Alluvial soil has a high moisture content and is rich in nutrient content, one of which is the $\mathrm{N}$ element. $\mathrm{N}$ nutrients are essential nutrients that play a role in leaf formation. According to Geologinesia (2018) that the weathering of minerals in alluvial soils produces nutrients one of which is $\mathrm{N}$ which is very much needed for plant growth. According to Jumin (2002) nitrogen functions to stimulate budding and leaf formation. In line with the opinion of Lingga (1986) in Daryadi and Ardian (2017) states that nitrogen in sufficient quantities plays a role in accelerating overall plant growth, especially stems and leaves. Nyakpa et al. (1988) in Daryadi and Ardian (2017) stated that the process of leaf formation is inseparable from the role of nutrients such as $\mathrm{N}$ which plays a role in the formation of new cells and the main components making up organic compounds in plants.

\section{c. Number of Roots}

Table 3 shows that the highest number of roots of jasmine cuttings found in the treatment of rice husk planting media $\left(\mathrm{M}_{3}\right)$ which was significantly different from the treatment of sand planting media $\left(\mathrm{M}_{2}\right)$, but not significantly different from the alluvial soil planting media $\left(\mathrm{M}_{1}\right)$. 
Table 3. The average number of roots of jasmine cuttings in various media Planting

\begin{tabular}{lc}
\hline Handling & Number of Roots \\
\hline Alluvial soils $\left(\mathrm{M}_{1}\right)$ & $14,63 \mathrm{~b}$ \\
Sand $\left(\mathrm{M}_{2}\right)$ & $11,52 \mathrm{a}$ \\
Chaff Charcoal $\left(\mathrm{M}_{3}\right)$ & $16,37 \mathrm{~b}$ \\
\hline $\mathrm{BNT}_{0,05}$ & 1,84 \\
\hline
\end{tabular}

Note: Numbers followed by the same letters in the same column that are not significantly different in the $\mathrm{BNT}_{0.05}$ test

The husk charcoal media has a high carbon content that supports root growth. According to Prayugo (2007), one of the advantages of rice husk planting media is that it has a high carbon content (C). Rochiman and Harjadi (2003) stated that what affects root growth in cuttings is the carbon content in the planting medium. Media cuttings that have a high $\mathrm{C}$ make it easy to form roots and shoots.

According to Wulandari et al. (2017), rice husk planting media is able to provide good root growth because it has high porosity, as well as good aeration and draenase. Mangoendijodjojo (2003) states that a good planting medium for cuttings must be able to provide sufficient moisture and good aeration as a place of root formation.

The number of roots of jasmine plant cuttings is not significantly different from the treatment of alluvial soil planting media $\left(\mathrm{M}_{1}\right)$, this is presumably because alluvial soil has the ability to absorb water that is good enough to support root growth. According to Geologinesia (2018) alluvial soils are sedimentary soils, these sediments have good water absorption abilities. That way the plants that grow on it will not dry out because they have enough water reserves. Plant roots will absorb water in the soil so that it can grow well even in the dry season.

According to Ashari (1995), the main thing in the success of propagation of plants with cuttings is the growth of roots not shoots, because the roots are very important for the absorption of water and nutrients to support the growth of shoots and subsequent leaves. Yasman and Smits (1984) in Irwanto (2001) stated that the texture and influence of the rooting process when compared with its chemical properties such as acidity and others.

\section{d. Root Length}

Based on Table 4.4, the longest root cuttings of jasmine plants were found in the treatment of rice husk planting media $\left(\mathrm{M}_{3}\right)$ which were significantly different from the treatment of sand planting media $\left(\mathrm{M}_{2}\right)$, but not significantly different from the alluvial soil planting media $\left(\mathrm{M}_{1}\right)$. This is presumably because the rice husk planting media contains nutrients that support root growth. Nutrients contained in the husk charcoal support the formation of roots. 
Table 4. The average length of jasmine root cuttings in various plants Growing media

\begin{tabular}{lc}
\hline Handling & Root length $(\mathrm{cm})$ \\
\hline Alluvial soils $\left(\mathrm{M}_{1}\right)$ & $14,94 \mathrm{~b}$ \\
Sand $\left(\mathrm{M}_{2}\right)$ & $12,29 \mathrm{a}$ \\
Chaff Charcoal $\left(\mathrm{M}_{3}\right)$ & $17,13 \mathrm{~b}$ \\
\hline BNT $_{0,05}$ & 2,44 \\
\hline
\end{tabular}

Note: Numbers followed by the same letters in the same column that are not significantly different in the $\mathrm{BNT}_{0.05}$ test

According to Mas'ud (1993) in Wulandari et al. (2017) root development depends on nutrient availability and supply. Husk charcoal can increase fertility because it contains nutrients as well as several types of organic matter (Wulandari et al., 2017). These properties can improve the physical and chemical properties of the soil. Fahrudin (2009) states that if roots grow well, the growth of other plant parts will develop well too, because the roots can absorb nutrients needed by plants.

The length of the roots of jasmine plant cuttings is not significantly different from the treatment of alluvial soil planting media $\left(\mathrm{M}_{1}\right)$, this is presumably because alluvial soil contains nutrients that support root growth. According to Amuzigi (2018) alluvial soils can be categorized as fertile soils because a lot of nutrients are also carried by the flow of water which causes erosion from the upstream to downstream of the river.

\section{e. Life Percentage (\%)}

The results showed that the percentage of the best growth of jasmine cuttings was found in the treatment of rice husk $\left(\mathrm{M}_{3}\right)$ and alluvial soil $\left(\mathrm{M}_{1}\right)$ planting media (Table 5). This shows that the husk charcoal and alluvial soil are able to provide good water, nutrients and growth space. In accordance with the opinion of Gardner and Mitchell (1991) in Merlyn (2017), that a good planting media is a medium that is able to provide enough water and nutrients, this can be determined on a planting medium with good air and water management, which has a good aggregate. steady, good water holding ability and growing space for sufficient rooting. Alluvial soil as a type of soil that has good water absorption and storage capabilities, alluvial soils are very suitable to be used as plant media (Amuzigi, 2018).

Table 5. the average percentage of life of jasmine cuttings in various plants Growing media

\begin{tabular}{lc}
\hline Handling & Root length $(\mathrm{cm})$ \\
\hline Alluvial soils $\left(\mathrm{M}_{1}\right)$ & $80,00 \mathrm{~b}$ \\
Sand $\left(\mathrm{M}_{2}\right)$ & $57,78 \mathrm{a}$ \\
Chaff Charcoal $\left(\mathrm{M}_{3}\right)$ & $82,22 \mathrm{~b}$ \\
\hline $\mathrm{BNT}_{0,05}$ & 22,90 \\
\hline
\end{tabular}

Note: Numbers followed by the same letters in the same column that are not significantly different in the $\mathrm{BNT}_{0.05}$ test 
Chemically, the husk charcoal contains important nutrients such as nitrogen $(\mathrm{N})$, phosphorus $(\mathrm{P})$, potassium $(\mathrm{K})$, calcium $(\mathrm{Ca})$ and Magnesium $(\mathrm{Mg})$. Its acidity is neutral to alkaline with a $\mathrm{pH}$ range of 6.5 to 7 (Surdianto et al., 2015). According to Geologinesia (2018) alluvial soil is derived from soil sediment material so that alluvial soil contains nutrients such as nitrogen $(\mathrm{N})$, phosphorus $(\mathrm{P})$, potassium $(\mathrm{K})$ which are important for plants. Amuzigi (2018) states that erosion from upstream to downstream of the river causes a lot of nutrients to be transported by the flow of water, so that alluvial soils are categorized as soils fertile.

\subsection{Effects of Growth Regulatory Substances}

\section{a. Number of Buds}

The highest number of Jasmine cuttings buds 35 and 45 HST were found in the treatment of organic growth regulating agent $\left(Z_{2}\right)$ which was significantly different from the control treatment $\left(Z_{0}\right)$, but not significantly different from the treatment of chemical growth regulating agent $\left(Z_{1}\right)$ (Table 6). This is presumably because the hormone content of the onion can increase the number of shoots.

Table 6. The average number of jasmine cuttings buds 15, 35 and HST on some growth regulators

\begin{tabular}{lccc}
\hline \multirow{2}{*}{ Handling } & \multicolumn{4}{c}{ Number of buds } \\
\cline { 2 - 4 } & 15 HST & 35 HST & 45 HST \\
\hline Control $\left(\mathrm{Z}_{0}\right)$ & 0,96 & $1,74 \mathrm{a}$ & $2,85 \mathrm{a}$ \\
Chemistry $\left(\mathrm{Z}_{1}\right)$ & 1,22 & $2,37 \mathrm{~b}$ & $3,52 \mathrm{~b}$ \\
Organic $\left(\mathrm{Z}_{2}\right)$ & 1,33 & $1,63 \mathrm{~b}$ & $3,78 \mathrm{~b}$ \\
\hline \multicolumn{1}{c}{ BNT $_{0,05}$} & - & 0,45 & 0,61 \\
\hline
\end{tabular}

Note: Numbers followed by the same letters in the same column that are not significantly different in the $\mathrm{BNT}_{0.05}$ test

Provision of growth regulators onion extract showed the highest average number of leaves from the level of other factors. This condition is caused by the presence of hormones such as cytokines and auxins contained in onion extract which can stimulate leaf growth in jasmine cuttings. In addition to cytokinins and auxins, onion extract also contains essential oils, cycloaliin, methylaliin, dihydroaliin, flavonglycosides, quercetin, saponins, peptides, phytohormones, vitamins, and starch which all play a role in the process of plant metabolism (Muswita, 2011).

The highest number of jasmine cuttings of 35 and 45 HST was also found in the treatment of organic growth regulating agent $\left(Z_{2}\right)$ which was not significantly different from the treatment of chemical growth regulating agent $\left(Z_{1}\right)$, this was allegedly because Growtone growth regulators were auxin groups which could accelerate the physiological process in plants, which results in the formation of shoots on cuttings. Shiddiqi et al. (2012) stated that auxin absorbed by plant tissue will activate food reserve energy and increase cell division, cell elongation and differentiation which ultimately form buds and bud elongation processes. 


\section{b. Number of Leaves (Strands)}

The highest number of leaves of 15 HST was found in the treatment of organic growth regulators $\left(\mathrm{Z}_{2}\right)$ (Table 6). This shows that allin compound in onion extract can stimulate cells in leaf formation. Based on the statement of Meutia et al. (2009) that results of secondary metabolites from shallots are allin compounds which are immediately transformed into thiosulfinic compounds, such as allicin, with the help of the alliinase enzyme

Table 7. The average number of jasmine cuttings leaves 15, 35 and HST on some growth regulators

\begin{tabular}{lccc}
\hline \multirow{2}{*}{ Handling } & \multicolumn{4}{c}{ Number of leaves (sheet) } \\
\cline { 2 - 4 } & 15 HST & 35 HST & 45 HST \\
\hline Control $\left(Z_{0}\right)$ & $3,30 \mathrm{a}$ & $12,30 \mathrm{a}$ & $19,33 \mathrm{a}$ \\
Chemistry $\left(\mathrm{Z}_{1}\right)$ & $4,30 \mathrm{~b}$ & $16,07 \mathrm{~b}$ & $25,15 \mathrm{~b}$ \\
Organic $\left(\mathrm{Z}_{2}\right)$ & $4,81 \mathrm{~b}$ & $17,19 \mathrm{~b}$ & $28,63 \mathrm{~b}$ \\
\hline \multicolumn{1}{c}{$\mathrm{BNT}_{0,05}$} & 0,71 & 1,58 & 3,53 \\
\hline
\end{tabular}

Note: Numbers followed by the same letters in the same column that are not significantly different in the $\mathrm{BNT}_{0.05}$ test

Rahayu et al. (2004) states that the compound allicin with thiamin (vitamin B1) can form chemical bonds called allithiamin. The existence of these substances can accelerate metabolism in plant tissue and can mobilize food ingredients that are in the body of the plant, so that if the metabolic process is smooth it will be able to increase the average number of leaves in plants.

The highest number of leaves of 35 HST was found in the treatment of organic growth regulating agent $\left(Z_{2}\right)$ which was not significantly different from the treatment of chemical growth regulating agent $\left(Z_{1}\right)$ (Table 6). This is because both shallots and Growtone contain auxin hormone which functions as a regulator of cell enlargement and triggers cell elongation in the area behind the tip of the meristem. In accordance with the opinion of Hermansyah (2000), that plant growth is basically caused by cell enlargement and cell division, so the number of cells can be used as an indicator of plant growth or plant organs, such as leaves.

The increasing number of jasmine cuttings of $45 \mathrm{HST}$ in the treatment of organic $\left(\mathrm{Z}_{2}\right)$ and chemical growth regulators $\left(Z_{1}\right)$ (Table 6$)$, this is presumed because the auxin content in both zpt stimulates the formation of more leaves than without the administration of zpt. Suwarno (2010) states that the administration of auxin at the beginning of planting can stimulate the growth of buds and leaf formation cells quickly, so that the next stage of the process of photosynthesis occurs in addition to that growth without growth regulators shows the smallest number of leaves. This is because the shoots formed are no longer than the treatment of organic and chemical growth regulators.

\section{c. Number of Roots}

Table 8 shows that the most number of roots of jasmine cuttings found in the treatment of chemical growth regulators $\left(Z_{1}\right)$ were significantly different from the control treatments $\left(Z_{0}\right)$, but not significantly different from the treatments of organic growth regulators $\left(Z_{2}\right)$ 
Table 8. The average number of roots of jasmine plant cuttings on several substances regulator

\begin{tabular}{lc}
\hline Handling & Number of roots \\
\hline Control $\left(\mathrm{Z}_{0}\right)$ & $11,70 \mathrm{a}$ \\
Chemistry $\left(\mathrm{Z}_{1}\right)$ & $16,15 \mathrm{~b}$ \\
Organic $\left(\mathrm{Z}_{2}\right)$ & $14,67 \mathrm{~b}$ \\
\hline $\mathrm{BNT}_{0,05}$ & 1,84 \\
\hline
\end{tabular}

Note: Numbers followed by the same letters in the same column that are not significantly different in the $\mathrm{BNT}_{0.05}$ test

The increasing number of jasmine plant cuttings in the treatment of chemical growth regulators $\left(\mathrm{Z}_{1}\right)$, due to growtone $\mathrm{ZPT}$ contains synthetic auxins that play a role in the growth of cuttings roots. This can be understood considering the function of auxin which affects physiological processes such as membrane permeability, encouraging cell enlargement in the stem, accelerating the enlargement of root cells, and increasing the number of roots (Abidin, 1990). Some known synthetic auxins are IBA (Indolebutyric acid), NAA (Naphthaleneacetic acid) and 2,4-D (Dichloro Phenoxy Acetic Acid). According to Hardiansyah (2018), growtone contains active ingredients from the formulation of several growth hormone hormones namely IBA, the use of growtone can stimulate root cuttings.

The number of roots of jasmine cuttings was not significantly different from the treatment of organic growth regulators $\left(Z_{2}\right)$, allegedly because the onion extract contained auxin in the form of IAA which could stimulate root formation. Nurlaeni (2015) states that the administration of PGR which contains auxin is able to provide growth in the number and length of roots. Auxin acts as an initial driver for the process of root formation in cuttings. The addition of exogenous auxin will increase the content of endogenous auxin in the network cuttings so that it can initiate cells to grow and develop which will then differentiate to form organs such as roots (Muswita, 2011). Shallot extract contains auxin in the form of IAA (Indoleacetic acid). Research by Suparjo et al. (2016) showed the influence of IAA on shoot height and number of leaves of binahong plants through micro propagation.

\section{d. Root Length (cm)}

Based on Table 4.9, the longest root length of cuttings of jasmine plants was found in the treatment of chemical growth regulating agent $\left(Z_{1}\right)$ which was significantly different from the control treatment $\left(Z_{0}\right)$, but not significantly different from the treatment of organic growth regulator $\left(\mathrm{Z}_{2}\right)$. That is because the auxin hormone in zpt growtone can increase the cell elongation process, in this case the root cell. Auxin causes the recipient cells in the plant to emit hydrogen ions around the cell walls which in turn lowers the $\mathrm{pH}$ and causes thinning of the cell wall, and there is growth associated with root cell lengthening (Darojat et al., 2015). 
Table 9. The average length of jasmine root cuttings in several Growth regulator

\begin{tabular}{ll}
\hline Handling & Root length \\
\hline Control $\left(\mathrm{Z}_{0}\right)$ & $12,01 \mathrm{a}$ \\
Chemistry $\left(\mathrm{Z}_{1}\right)$ & $16,71 \mathrm{~b}$ \\
Organic $\left(\mathrm{Z}_{2}\right)$ & $15,64 \mathrm{~b}$ \\
\hline $\mathrm{BNT}_{0,05}$ & 2,44 \\
\hline
\end{tabular}

Note: Numbers followed by the same letters in the same column that are not significantly different in the $\mathrm{BNT}_{0.05}$ test

Rusmin (2011) states that the work of auxin is by influencing the relaxation or flexing of the cell wall. Plant cells then elongate due to osmotic water entering. After this elongation, cells continue to grow and re-synthesize cell wall material and cytoplasm. Cell lengthening causes root lengthening.

Growtone contains active ingredients resulting from the formulation of several root growth hormones such as IBA. In addition, synthetic auxin, IBA, is reported to be more effective in stimulating root formation than natural auxin. IBA is a synthetic auxin that is widely used for rooting stem cuttings (Hartmann et al., 2011).

The increase in root length in the application of zpt growtone, due to zpt growtone is a group of auxins that affect cell elongation activity thereby stimulating root length growth. Cell elongation occurs because auxin influences the development and flexing of the cell wall. Auxin stimulates certain proteins in the plasma membrane of plant cells to pump $\mathrm{H}$ ions into the cell wall (Hidayanto et al., 2007 in Ardaka et al., 2011).

\section{e. Life Percentage}

The results showed that the highest percentage of live cuttings was found in the treatment of organic growth regulators $\left(\mathrm{Z}_{2}\right)$ (Table 4.10).

Table 10. The average percentage of life of jasmine cuttings on some growth regulators

\begin{tabular}{ll}
\hline Handling & Life Percentage \\
\hline Control $\left(\mathrm{Z}_{0}\right)$ & $62,22 \mathrm{a}$ \\
Chemistry $\left(\mathrm{Z}_{1}\right)$ & $77,78 \mathrm{~b}$ \\
Organic $\left(\mathrm{Z}_{2}\right)$ & $80,00 \mathrm{~b}$ \\
\hline $\mathrm{BNT}_{0,05}$ & 12,90 \\
\hline
\end{tabular}

Note: Numbers followed by the same letters in the same column that are not significantly different in the $\mathrm{BNT}_{0.05}$ test

This is thought to be the effect of onions containing allin compounds needed for metabolism in plant tissue thereby increasing the percentage of cuttings growth. Marfirani et al. (2014), states that onion extract there is a compound called allin which will then turn into a thiosulfinic compound such as allicin. Allicin with thiamin (vitamin B) forms allithiamin which accelerates metabolism in plant tissues.

The life percentage of organic growth regulating agent $\left(\mathrm{Z}_{2}\right)$ was not significantly 
different from the chemical growth regulator treatment $\left(Z_{1}\right)$, this is because ztone growtone contained auxin compounds which stimulated the growth of cuttings. Growtone is one of the ZPT which is included in the auxin group which contains naphthalene and indole compounds which are stimulating the development of adventitious root meristems so that it triggers plant growth. The function of auxin can influence physiological processes such as encouraging the enlargement of cells in the stem, accelerating the enlargement of root cells and increasing the number of roots so that it can trigger better growth (Abidin, 1990).

\section{Conclusion}

Planting media have very significant effect on the number of shoots 35 and 45 HST, number of leaves 15,35 and 45 HST number of roots, root length, percentage of live cuttings. But no significant effect on the number of shoots 15 HST.

Growth regulator has a very significant effect on the number of buds 35 HST, number of leaves 15,35 and $45 \mathrm{HST}$, number of roots and root length. Significantly affected the number of shoots 45 HST and the percentage of live cuttings. But no significant effect on the number of shoots 15 HST. There was no interaction between planting media and growth regulators on all observed growth variables of jasmine cuttings.

\section{References}

Abidin, Z 1990. Dasar-dasar Pengetahuan Tentang Zat Pengatur Tumbuh. Penerbit Angkasa Bandung.

Adriance, GW andn Brisco FR. 1979. Propagation of horticurtural plants. R. E. Krieger Pub. Co. Michigan. 298 p.

Amuzigi. 2018. Tersedia pada https://www.amuzigi.com/ 2018/ 04/tanah-aluvial-ciri karakteristik-dan.html. Diakses pada Tanggal 20 September 2019.

Ardaka IM, Tirta IG dan Darma DBP. 2011. Pengaruh Jumlah Ruas dan Zat Pengatur Tumbuh terhadap Pertumbuhan Stek Pranajiwa (Euchresta horsfieldi (Lesch) Benth). Balai Konservasi Tumbuhan Kebun Raya Bali. www.google.co.id. 21 halaman. Di akses 2 Desember 2018.

Artati FY. 2007, Pengaruh Macam Pupuk Organik Cair dan Konsentrasi IAA terhadap Pertumbuhan Stek Tanaman Stevia (Stevia rebaudiana Bertoni M.). [Skripsi]. Fakultas Pertanian. Universitas Negeri Surakarta.

Ashari. 1995. Hortikultura Aspek Budidaya. Buku. Penerbit Universitas Indonesia. Jakarta. $141--146 \mathrm{p}$.

Darojat MK, Resmisari RS dan Nasichuddin A. 2015. Pengaruh Konsentrasi dan Lama Perendaman Ekstrak Bawang Merah (Allium cepa L.) terhadap Viabilitas Benih Kakao (Theobroma cacao L.). Jurnal Penelitian Universitas Islam Negeri Maulana Malik Ibrahim. Malang.

Daryadi dan Ardian. 2017. Pengaruh Pemberian Kompos Ampas Tahu dan Pupuk NPK terhadap Pertumbuhan Bibit Kakao (Theobroma cacao L.). JOM FAPERTA. Vol. 4 (2): $1-14$.

Fahrudin F. 2009. Budidaya Caisim (Brassica juncea L.) Menggunakan Ekstrak Teh dan Pupuk Kascing. Surakarta : Universitas Sebelas Maret.

Fatchuroman A. 2018. Respon Pertumbuhan Stek Tanaman Mucuna (Mucuna bracteata D.C) Terhadap Kosentrasi ZPT Growtone dan dosis pupuk kandang. (Skripsi).Universitas Teuku Umar. 
Goeloginesia. 2018. https://www.geologin- esia.com/2018/01/tanah-aluvial.html. Diakses pada Tanggal 25 September 2019.

Hayati E, Sabaruddin dan Rahmawati. 2012. Pengaruh Jumlah Mata Tunas dan Komposisi Media Tanam terhadap Pertumbuhan Stek Tanaman Jarak Pagar (Jatropha curcus L.). Agrista. Vol. 16(3):1-16.

Hardiansyah J. 2018. Pengaruh Lama Perendaman dari Berbagai ZPT terhadap Pertumbuhan Stek Batang Jeruk Nipis. [Skripsi]. Fakultas Pertanian. Universitas Muhammadiyah Sumatera Utara.

Hartman HT, Kester DE, Davis FT, Geneue JRRL, 2011. Plant Propagation, Principles and Practices. 7th edition. Prentice Hall Inc: p. 770.

Hermansyah A, Armaini, Erlida. 2000. Pengaruh Perbedaan Konsentrasi Zpt Dan Sistem Pembibitan Terhadap Pertumbuhan Bibit Buah Naga (Hylocereus costaricensis). Jurnal Jurusan Agroteknologi Fakultas Pertanian Universitas Riau.

Irwanto. 2001. Pengaruh Hormon IBA (Indole Butyric Acid) terhadap Persen Jadi Stek Pucuk Meranti Putih (Shorea montigena). [Skripsi]. Universitas Pattimura. Ambon

Jumin HB. 2002. Agronomi. PT. Raja Grafindo Persada, Jakarta

Marfirani M, Yuni SR, dan Evie R. 2014. Pengaruh Berbagai Konsentrasi Filtrat Umbi Bawang Merah dan Rootone F terhadap Pertumbuhan Stek Melati "Rato Ebu". Universitas Negeri Surabaya. Lentera Bio. Vol. 3 (1).

Maulana Y. 2007. Budidaya Bunga Melati. CV. Sinar Cemerlang Abadi, Jakarta.

Merlyn M. 2017. Pengaruh Media Tanam terhadap Pertumbuhan Stek Batang Nilam (Pogostemon cablin Benth). Agrica Ekstensia. Vol. 11 (1):1-8.

Meutia A, Yustikawati dan Nisa M. 2009. Kolaborasi Tempe dan Bawang Putih. Jurnal Hortikultura, Bogor.

Muswita. 2011. Pengaruh Konsentrasi Bawang Merah (Alium cepa L.) terhadap Pertumbuhan Stek Gaharu (Aqualaria malaccensis OKEN). Jurnal Penelitian Universitas Jambi Seri Sains. Vol. 16 (2): 63-68.

Nurlaeni Y. dan Surya MI. 2015. Respon Stek Pucuk Camelia japonica terhadap Pemberian Zat Pengatur Tumbuh Organik. Prosiding Seminar

Nasional Masyarakat Biodiversifikasi Indonesia. Vol. 1 (5): 1211-1215

Prameswari ZK, Trisnawati dan Waluyo. 2014. Pengaruh Macam Media dan Zat pengatur Tumbuh terhadap Keberhasilan Cangkok Sawo (Manilkara zapota (L.) Van Royen) pada Musim Penghujan. Vegetalika. Vol. 3 (4):107-118.

Prayugo S. 2007. Media Tanam untuk Tanaman Hias. Penebar Swadaya. Jakarta.

Rahayu E, dan Berlian N, 2004. Mengenal Varietas Unggul dan Cara Bududaya Secara Kontinyu Bawang Merah. PT Penebar Swadaya, Jakarta.

Rusmin D. 2011. Pengaruh Pemberian GA3 Pada Berbagai Konsentrasi dan Lama Inbibisi Terhadap Peningkatan Viabilitas Benis Puwoceng (Pimpinella pruatjan Molk.). Jurnal Littri. Vol. 17 (3).

Shiddiqi UA. Murniati. Dan Sukemi. 2012. Pengaruh Pemberian Zat Pengatur Tumbuh Terhadap Pertumbuhan Bibit Stum Mata Tidur Tanaman Karet (Hevea brasilliensis). Jurnal Fakultas Pertanian. Universitas Riau.

Suwarno. 2010. Tahap-Tahap Pertumbuhan Tanaman. http://www Tahaptahappertumbuhantanaman.com. Diakses pada tanggal 17 September 2019.

Supriyanto H. 2008. Pengaruh B-9 Tanah dan Pupuk Daun terhadap Pertumbuhan dan Pembungaan Anggrek Dendrobium sp. var THONGCHAI 'VIROJ'. (Skripsi). Program Studi Hortikultura.

Suparjo, Juwartina IR., Syofi R, Teuku T, dan Ahmad R. 2016. Pengaruh Auksin dan Sitokinin terhadap Perbanyakan Mikro Tanaman Binahong (Anredera cordifolia (Tenore) Steenis). Jurnal Bioteknologi dan Biosains Indonesia, Vol. 3 (2). 
Surdianto Y, Sutrisna N, Basuno dan Solihin. 2015. Cara Membuat Arang Sekam Padi. Balai Pengkajian Teknologi Pertanian (BPTP). Jawa Barat.

Tarigan PL, Nurbaiti, dan Sri Y. 2017. Pemberian ekstrak bawang merah sebagai zat pengatur tumbuh alami pada pertumbuhan stek lada (piper negrum L.). JOMFAPARTA vol 4 (1).

Winarso S. 2003. Kesuburan Tanah, Dasar Kesehatan dan Kualitas Tanah. Gava, Yogyakarta.

Wulandari F, Astiningrum M, dan Tujiyanta. 2017. Pengaruh Jumlah Daun dan Macam Media Tanam pada Pertumbuhan Stek Jeruk Nipis. Jurnal Ilmu Pertanian Tropika dan Subtropika. Vol. 2 (2): 48-51.

Wuryaningsih S. 1998. Pertumbuhan Stek Melati Berbuku Satu dan Dua pada Beberapa Macam Media. Agri Journal. Vol. 5 (1-2): 32-41.

Wuryaningsih S, Satsiyati danAndyantoro S. 2000. Pengaruh Kultivar, IBA, Dan Bahan Setek Pada Perbanyakan Melati. J.Agrotropika2 :26-30.

Wuryaningsih S. 2008. Media Tanam Tanaman Hias. Tersedia pada http://www.kebonkembang.com. diakses tangga 122 Februari 2019

Zainal, M. (2019). Growth Response and Crop Production (Brassica Juncea L.) Against Watering Time Interval at Various Hydroponics Media. Budapest International Research in Exact Sciences (BirEx) Journal. P.9-22. 